\title{
EFFECT OF LOW BIRTH WEIGHT ON THE LANGUAGE DELAY IN CHILDREN: META-ANALYSIS
}

\author{
Ruliany Yuni Nurul Hakim1), Setyo Sri Rahardjo²), \\ Yulia Lanti Retno Dewi2) \\ ${ }^{1)}$ Masters Program in Public Health, Universitas Sebelas Maret \\ 2)Faculty of Medicine, Universitas Sebelas Maret
}

\begin{abstract}
Background: Previous studies reported that low birth weight children have higher rates of subnormal growth, illnesses, and neurodevelopmental problems. Children with development delay inhibit them to attain failure new development. This study aimed to explore the effect of low birth weight on the language delay in children using metaanalysis.

Subjects and Method: A systematic review and meta-analysis was conducted by PRISMA flow diagram. The articles were collected from Google Scholar, Pubmed, and Research Gate databases. Keywords used "Low Birth Weight" AND "Language Delay" "AND "observational study" AND "adjusted odd ratio". The inclusion criteria were full text, observational studies published from year 2008 to 2020, used English language, and reported Odds Ratio. Articles that met the criteria were analyzed by Revman 5.3.

Results: 5 studies from India, Thailand, Taiwan, Japan, and Cairo were reviewed for meta-analysis. This study found that low birth weight increased the risk of language delay in children $(\mathrm{aOR}=2.52 ; 95 \% \mathrm{CI}=1.90$ to $3.35 ; \mathrm{p}<0.001)$.
\end{abstract}

Conclusion: Low birth weight increased the risk of language delay in children.

Keywords: low birth weight, language delay, language development

\section{Correspondence:}

Ruliany Yuni Nurul Hakim. Masters Program in Public Health, Universitas Sebelas Maret. Jl. Ir. Sutami 36A, Surakarta 57126, Central Java. Email: Ruliany27@gmail.com. Mobile: 082124886320 